\title{
Characterization and influence of fine recycled aggregates on masonry mortars properties
}

\author{
P. Saiz-Martínez ${ }^{\mathrm{a}} \bowtie$, M. González-Cortina ${ }^{\mathrm{a}}$, F. Fernández-Martínez ${ }^{\mathrm{b}}$ \\ a. Technical University School of Architecture, Madrid Polytechnic University (Madrid, Spain) \\ b. University school of Technical Industrial Engineering, Technical University of Madrid (Madrid, Spain) \\ هpablo.saiz@upm.es
}

Received 2 September 2014

Accepted 21 January 2015

Available on line 5 June 2015

\begin{abstract}
This research aims to study mechanical behaviour and relevant properties of masonry mortars fabricated using fine recycled aggregate in different mixture proportions. Fine recycled aggregates samples originated from the ceramic and concrete recycling process and coming from two recycling plants of Madrid region have been used. Tests were performed using 1:3:0.5 volumetric cement-to-aggregate-to-water ratio. Standardized sand with fine recycled aggregate replacement percentages were: $10 \%, 15 \%, 25 \%, 35 \%$ and $45 \%$.

A continuous size distribution curve can be observed and the main crystalline phases determined have been quartz, calcite and gypsum. Compressive strength, shrinkage and bond strength tests revealed poorer performance of recycled mortars compared to the conventional mortars; however, specific values are within the limits established by the manufacturers and standards. This study shows that cement-based mortars prepared with volumetric ratio 1:3:0.5 may contain up to $45 \%$ of fine recycled aggregates, without their properties being affected and without presenting significant losses.
\end{abstract}

KEYWORDS: Mortar; Waste treatment; Aggregate; Characterization; Mechanical properties

Citation/Citar como: Saiz-Martínez, P.; González-Cortina, M.; Fernández-Martínez, F. (2015) Characterization and influence of fine recycled aggregates on masonry mortars properties. Mater. Construcc. 65 [319], e058 http://dx.doi. $\operatorname{org} / 10.3989 / \mathrm{mc} .2015 .06014$

RESUMEN: Caracterización e influencia del arido reciclado fino en las propiedades de los morteros de albañilería. Esta investigación estudia el comportamiento mecánico y las propiedades más relevantes de los morteros de albañilería fabricados usando arenas recicladas en diferentes proporciones. Muestras pertenecientes a la línea de reciclaje cerámica y de hormigón proceden de dos centrales de reciclaje de la Comunidad de Madrid. Los ensayos se realizaron con una dosificación 1:3:0,5. Los porcentajes de arena reciclada fueron: $10 \%, 15 \%, 25 \%$, $35 \%$ y $45 \%$.

Se observa una línea granulométrica continua y las principales fases cristalinas encontradas son cuarzo, calcita y yeso. Los ensayos de resistencia a compresión, retracción y adherencia muestran un peor comportamiento en los morteros reciclados frente a los morteros elaborados con arena normalizada, aunque dentro de los límites establecidos por normativas y fabricantes. Se deduce que, los morteros de albañilería base cemento, pueden incorporar un $45 \%$ de arena reciclada con una dosificación 1:3:0,5 sin que las propiedades ensayadas se vean afectadas con pérdidas significativas de prestaciones.

PALABRAS CLAVE: Mortero; Tratamiento de residuos; Árido; Caracterización; Propiedades mecánicas

Copyright: (C) 2015 CSIC. This is an open-access article distributed under the terms of the Creative Commons Attribution-Non Commercial (by-nc) Spain 3.0 License. 


\section{INTRODUCTION}

Aggregates are raw materials that have a crucial importance in the construction sector and economic development of a country. Unceasing activity in the construction sector during the last years before the crisis has produced a high generation of waste and an increase in the use of raw materials. The construction sector should give a solution to this problem and offer a sustainable model to minimize the negative effects of its activity, in terms of waste production, proposing proper waste management, assessment, reutilization and recycling.

In Spain the amount of recycled construction and demolition waste is quite lower than the objective established by the Integrated Waste Management Plan. The situation in Europe however, is better, since the average recycling rate is $50 \%$, and even some countries such as Denmark, Estonia and the Netherlands reach more than $90 \%$ construction and demolition waste recycling rate (1).

Presently the construction and demolition waste is used mainly as packing for highways stretches. In Spain, the use of the coarse fraction of this type of waste in concrete production is regulated by the Structural Concrete Code (EHE-08), recommending substitution of up to $20 \%$ of natural sand by recycled aggregate. However, the fine recycled aggregate has not been considered by most standards to be used in concrete preparation until now. Therefore, the incorporation of this material in masonry mortars production implies a new alternative for recycling construction and demolition waste in the building and construction sector.

Various scientific researchers have studied the feasibility of incorporating fine fraction of recycled aggregate in masonry mortars production. One of the main inconveniences of such type of material is its heterogeneity. The characteristics of fine recycled aggregates can be affected by the production process (2) and by the properties of previously demolished material (3). The quality of recycled aggregates in terms of physical, mechanical and chemical characteristics is determined mainly by the content of adhered mortar, contaminants and impurities $(2,4)$. Bonded mortar content may be reduced by increasing the crushing process performed in the treatment plants $(5,6)$.

Vegas et al. (7) studied the technical feasibility of using fine fraction recycled aggregate from concrete rubble. They concluded that these mortars can contain up to $25 \%$ of fine recycled aggregate without their mechanical properties, workability and shrinkage being affected, and requiring no additives.

Corinaldesi et al. (8) evaluated mechanical and rheological behaviour of cement mortars manufactured using three types of recycled aggregates: rejected prefabricated concrete material, recycled bricks waste and plant recycling rubble. The results show poorer mechanical behaviour than that of the reference one. Nevertheless, mortar-brick bond strength is higher in recycled mortars.

Other research studies to be pointed out are: the work of Jiménez et al. (9), who studied the incorporation of ceramic waste with up to $40 \%$ substitution in recycled mortars manufacture; and the work of Miranda et al. (10), who analysed properties of mortars incorporating recycled aggregates of different origin.

The findings obtained in this research contribute to the previously published articles, studying in depth the characteristics of recycled aggregates and their influence when used in masonry mortar manufacture, so as to achieve greater percentages of recycled aggregate incorporation rates.

\subsection{Objectives}

The main aim of this work is the physical and chemical characterization of fine fraction recycled aggregate, and to study the feasibility of incorporating this material in the masonry mortar production. To that end, construction and demolition samples from two recycling plants situated in Madrid region have been used. Two of them were obtained from concrete recycling processes, and one from the ceramic recycling line.

\section{MATERIALS AND METHODS}

\subsection{Materials}

The following materials were used in this research: cement, sand, additive and water.

\subsubsection{Cement}

The binder used in the study was CEM II/B L $32.5 \mathrm{~N}$, suitable for mortar production and for masonry in general. The properties of this cement are specified by Spanish and European standard UNE-EN 197-1 and by the Instruction for the cement placing (RC-08). The main characteristics are shown in Table 1.

\subsubsection{Aggregates}

Aggregates used to prepare mortars were provided by the Eduardo Torroja Institute, belonging to the Higher Council for Scientific Research, in case of standardized sand. In the case of recycled sand, it was provided by two integrated Construction and Demolition Waste Treatment Plants situated in Madrid Region. Three samples of recycled aggregates (RA) were used: fine recycled aggregates RA-1 and RA-2 from the "Palentina" plant belonging to ceramic recycling process, and to concrete recycling process respectively; fine recycled 
TABLE 1. CEM II/B-L $32.5 \mathrm{~N}$ characteristics

\begin{tabular}{lc}
\hline \multicolumn{2}{c}{ Physical characteristics } \\
\hline Density $\left(\mathrm{g} / \mathrm{cm}^{3}\right)$ & 3.08 \\
Blaine specific area $\left(\mathrm{cm}^{2} / \mathrm{g}\right)$ & 4000 \\
Initial set $(\mathrm{min})$ & 175 \\
Final set $(\mathrm{min})$ & 275 \\
\hline \multicolumn{2}{c}{ Chemical characteristics } \\
\hline Elements & Result (\%) \\
\hline $\mathrm{Al}_{2} \mathrm{O}_{3}$ & 3.25 \\
$\mathrm{CaO}$ & 60.10 \\
$\mathrm{Fe}_{2} \mathrm{O}_{3}$ & 2.56 \\
$\mathrm{~K}_{2} \mathrm{O}$ & 0.26 \\
$\mathrm{MgO}_{\mathrm{SiO}}$ & 1.75 \\
$\mathrm{TiO}_{2}$ & 18.13 \\
$\mathrm{MnO}_{2}$ & 0.14 \\
$\mathrm{P}_{2} \mathrm{O}_{5}$ & 0.02 \\
$\mathrm{NaO}_{2}$ & 0.16 \\
$\mathrm{Loss}_{2}$ on Ignition & 0.22 \\
\hline
\end{tabular}

aggregate RA-3 from the "Molar" plant originated from concrete recycling process.

\subsubsection{Additive}

The superplasticizer additive Rheobuild 2100 by BASF Company was used to prepare mortars with standardized sand substituted by fine recycled aggregate in levels higher than $10 \%$. This additive is a liquid product based on synthetic melamine polymers free from any substances that would have negative effects on mortars. Rheobuild 2100 was prescribed by BASF Company technical department to improve consistency of concrete mortars fabricated using fine recycled aggregates.

\subsection{Characterization of Recycled Aggregates}

Samples of fine recycled aggregates were characterized according to the technical requirements regulated by the standard UNE-EN-13139: "Aggregates for mortar". Three types of fine recycled aggregates comply with the upper and lower size limits and the maximum percentage of fines established by the standard for masonry mortars.

Complying with the specification in the UNE-EN-13139, all particles were smaller than $8 \mathrm{~mm}$ in size (2D) for the three types of recycled aggregates; and particles greater than $5.6 \mathrm{~mm}$ in size $(1,4 \mathrm{D})$ did not exceed $5 \%$ value determined as a limit. As for percentage of fines present in the samples of fine recycled aggregates passing through $0.063 \mathrm{~mm}$ sieve size, it did not exceed $8 \%$. This percentage was determined as a limit value for masonry mortars. The larger retained particles of three types of recycled aggregates were saved for crushing and the finer sieved $(<0.063 \mathrm{~mm})$ material was discarded.

Fine recycled aggregates size distribution was determined according to the requirements established by the UNE-EN-933-2 and the UNE-EN-933-1 standards, in particular Part 1: Determination of particle size distribution "Sieving method". Graphical representation of this test is shown in Figure 1.

As can be observed in Figure 1, the size distribution line is continuous for three types of recycled aggregates and does not exceed the limits established by the Basic Norm NBE-FL 90. Size distribution is one of the most important properties of aggregates, because it affects mortar compactness, workability and strength $(2,3)$. A continuous particle size distribution indicates that aggregates are uniformly graded in sizes, providing higher interaction between particles. Regarding physical characteristics of fine recycled aggregates, Table 2 summarizes the obtained values for: fine content, particle form, fineness modulus, bulk density, relative density and water absorption.

Three types of RA samples were also tested through X-Ray fluorescence method. Results of this test are shown in Table 3.

As can be observed, the fine fraction of three types of recycled aggregates is composed mainly of silicates, being the majority of them Calcium and Aluminium silicates. RA-1 presents high content of $\mathrm{Al}_{2} \mathrm{O}_{3}$, that can be explained by the higher quantities of clay and ceramics and the higher proportions of chert (11).

Obtained values of $\mathrm{CaO}$ and LOI fall between the range of values found in other researches (12). However, higher contents of these components were shown in other research that used aggregates originated from Italy (13).

Crystal structures and purity of the samples were tested by X-ray diffraction (XRD) analysis, where the $\mathrm{X}$-ray diffraction pattern was measured using the $\mathrm{Cu}-\mathrm{K} \alpha$ radiation $(\lambda=1.540598 \AA)$ with a Siemens D500 diffractometer equipped with a graphite monochromator. Data was collected at $300 \mathrm{~K}$ over an angular range of $10^{\circ} \leq 2 \leq 110^{\circ}$ by scanning in steps of $0.05^{\circ}$ and counting times of $10 \mathrm{~s}$. The results were analyzed by the Rietveld profile refinement method, using the FullProf Suite Program 1.10 (Version Oct2011). Figure 2 shows the diffractogram obtained for three samples used in this study. Table 4 summarizes different mineral phases. X-ray diffraction diagrams are similar for tested recycled aggregates and, with the exception of quartz, do not show a high crystalline state, although they have wide diffraction peaks with low intensities. This characteristic is typical of poorly crystalline and/or amorphous phases, due to low crystallinity of compounds formed as a result of concrete hydration and materials coming 


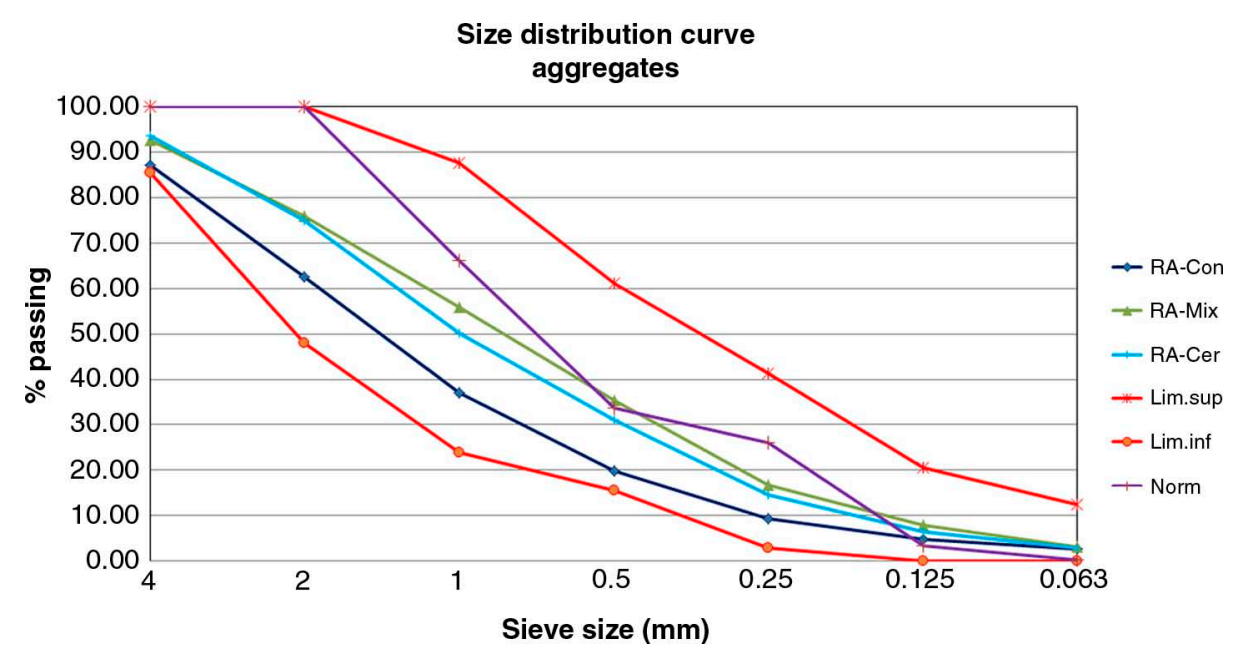

FIGURE 1. Recycled aggregate size distribution curve compared to the limits of NBE.FL 90 adapted to sieve size established by UNE-EN-933-2.

TABLE 2. Recycled aggregates characteristics summary

\begin{tabular}{llllll}
\hline \multicolumn{7}{c}{ Aggregates characteristics } \\
\hline Test & Norm & \multicolumn{1}{c}{ RA 1 } & \multicolumn{1}{c}{ RA 2 } & \multicolumn{1}{c}{ RA 3 } & Standardized \\
\hline Fine Content & UNE-EN-933-1 & $4.53 \%$ & $4.22 \%$ & $3.91 \%$ & $0.12 \%$ \\
Particle Form & UNE-EN-13139 & No relevant & No relevant & No relevant & No relevant \\
Fineness Modulus & UNE-EN-13139 & $4.77 \%$ & $4.12 \%$ & $4.26 \%$ & $3.71 \%$ \\
Bulk Dens. $\left(\mathrm{kg} / \mathrm{m}^{3}\right)$ & UNE-EN-1097-3 & 1210 & 1130 & 1320 & 1666 \\
Relative Dens. $\left(\mathrm{kg} / \mathrm{m}^{3}\right)$ & UNE-EN-1097-6 & 2130 & 2040 & 2100 & 2550 \\
Water absorption & UNE-EN-1097-6 & 7.48 & 6.35 & 6.12 & 0.68 \\
\hline
\end{tabular}

TABLE 3. Chemical analysis of RA

\begin{tabular}{lcccccccccccc}
\hline Samples & $\mathrm{Al}_{2} \mathbf{O}_{3}$ & $\mathbf{C a O}$ & $\mathrm{Fe}_{2} \mathbf{O}_{3}$ & $\mathbf{K}_{\mathbf{2}} \mathbf{O}$ & $\mathbf{M g O}$ & $\mathbf{S i O}_{2}$ & $\mathbf{M n O}$ & $\mathbf{T i O}_{2}$ & $\mathbf{S O}_{3}$ & $\mathbf{P}_{2} \mathbf{O}_{\mathbf{5}}$ & $\mathbf{N a}_{2} \mathbf{O}$ & $\mathbf{I . L o s s}^{*}$ \\
\hline RA-1 & 10.30 & 16.90 & 2.85 & 2.36 & 1.79 & 43.5 & - & 0.37 & 4.32 & 0.12 & 0.82 & 16.5 \\
RA-2 & 6.18 & 11.40 & 1.57 & 2.17 & 0.61 & 67.5 & 0.024 & 0.17 & - & 0,08 & 0.35 & 9.5 \\
RA-3 & 6.98 & 10.67 & 1.22 & 2.16 & 0.54 & 68.2 & 0.022 & 0,15 & - & 0,10 & 0.22 & 9.4 \\
\hline
\end{tabular}

from ceramics, that have additionally undergone the grinding process. Principal phases are quartz and calcite, other phases such as Albite, Sanidine, Phlogopite and Gypsum can also be observed.

Each recycled aggregate sample was tested through TGA-DTA method; Figure 3 shows an example of this test. As can be observed in the graphic, the RA samples weight loss and derivative weight loss are presented at the same temperature regions. In order to eliminate humidity, the samples were initially maintained during 5 minutes at $100{ }^{\circ} \mathrm{C}$. The first weight loss, -up to $110^{\circ} \mathrm{C}$-, is related to the samples humidity content, and above $160{ }^{\circ} \mathrm{C}-185^{\circ} \mathrm{C}$, decomposition of gypsum occurs. Above $570{ }^{\circ} \mathrm{C}$ a change of phase from $\alpha \mathrm{SiO}_{2}$ (alpha-quartz) to $\mathrm{BSiO}_{2}$ (beta-quartz) takes place, characterized by the endothermic peak under this temperature without mass loss. Between $650{ }^{\circ} \mathrm{C}$ and $750{ }^{\circ} \mathrm{C}$ the decarbonation of calcite is observed. The maximum temperature value obtained from the weight loss derivative curve $\left(720.18^{\circ} \mathrm{C}\right)$, representing the highest speed decomposition of different compounds is marked in the Figure 3. On the basis of the data shown in the diagram, calculating quantities of gypsum and calcite becomes possible. The X-ray diagram confirms the presence of these compounds. The calculated quantities of gypsum and calcite are shown in Table 4. 


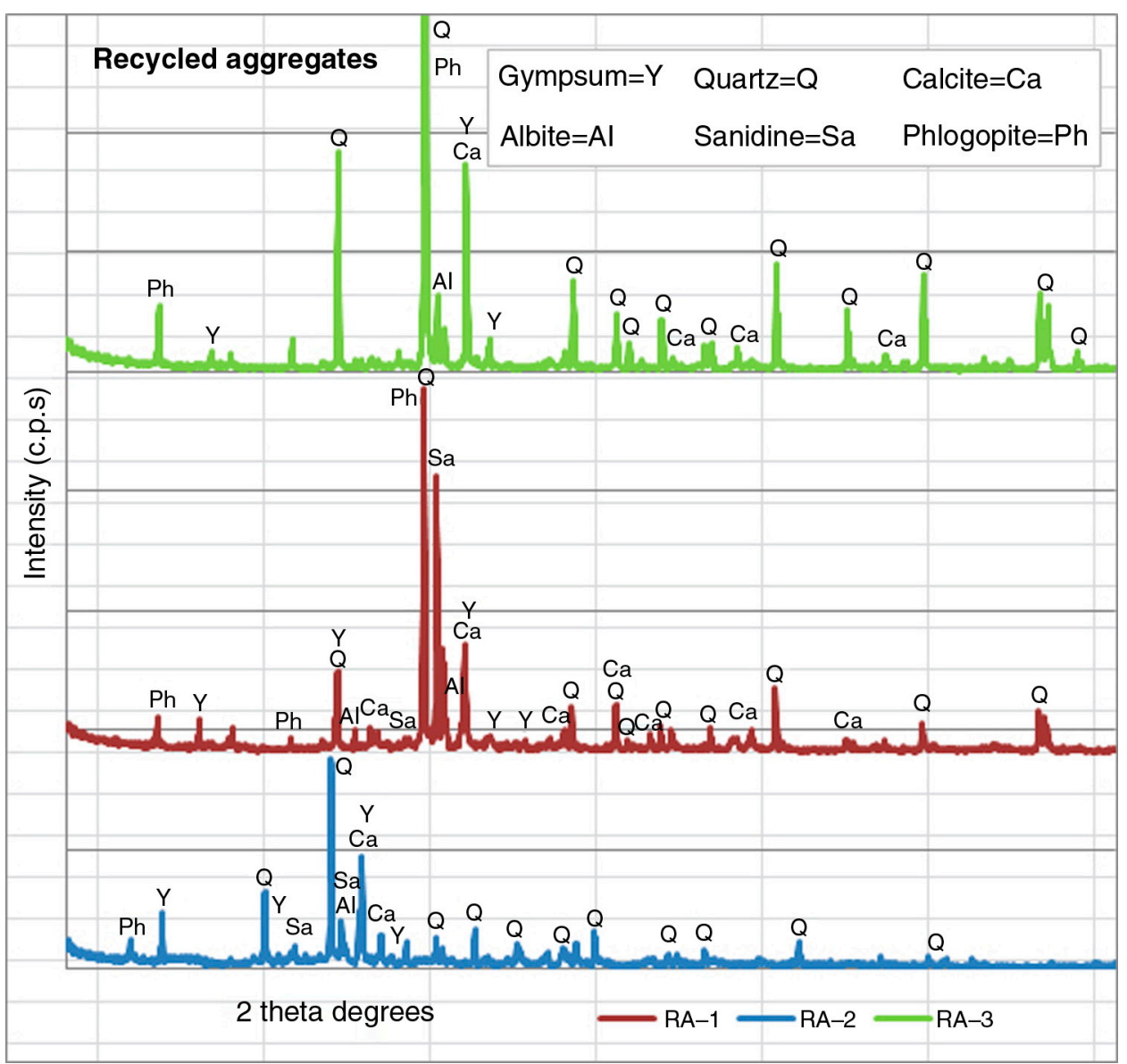

FIGURE 2. Diffractogram of recycled aggregates.

TABLE 4. Mineral phases observed in different samples. Gypsum and calcite content

\begin{tabular}{lcccccccc}
\hline \multicolumn{7}{c}{ Mineral Compounds } \\
\hline Sample & Sanidine & Calcite & Quartz & Gypsum & Albite & Phlogopite & \% Calcite & \% Gypsum \\
\hline RA-1 & X & X & X & X & X & X & 18.93 & 5.40 \\
RA-2 & X & X & X & X & & X & 17.10 & 4.32 \\
RA-3 & & X & X & X & X & X & 17.51 & 4.22 \\
\hline
\end{tabular}

\subsection{Proportions}

Once the recycled aggregates were characterized, the study of proportions and the development of a test plan were carried out. In this study a unique proportion was used to prepare recycled mortars: 1:3:0.5 (cement, sand and water respectively), and preparation of all mixes was performed using the same technique and equipment. In this way, the goal was to clearly determine the influence of recycled aggregates on masonry mortars, using standardized sand as a reference. Recycled aggregates obtained from the treatment plants were sieved in the laboratory, eliminating material retained on the
$4 \mathrm{~mm}$ sieve and material passed through $0.063 \mathrm{~mm}$ sieve. The amount of aggregate fractions reported in Table 5 refers to their dry condition. The percentages of fine recycled aggregates used were: $10 \%$, $15 \%, 25 \%, 35 \%$ and $45 \%$ for three types of recycled aggregates.

Mix design was structured in two stages, the first one without the use of additives. The second one was performed using the Rheobuild 2100 additive, following the recommendations of the manufacturer (BASF Company) regarding proportions and usage to obtain recycled mortars with characteristics similar to the reference mortars. According to the technical data, this additive can reduce the 


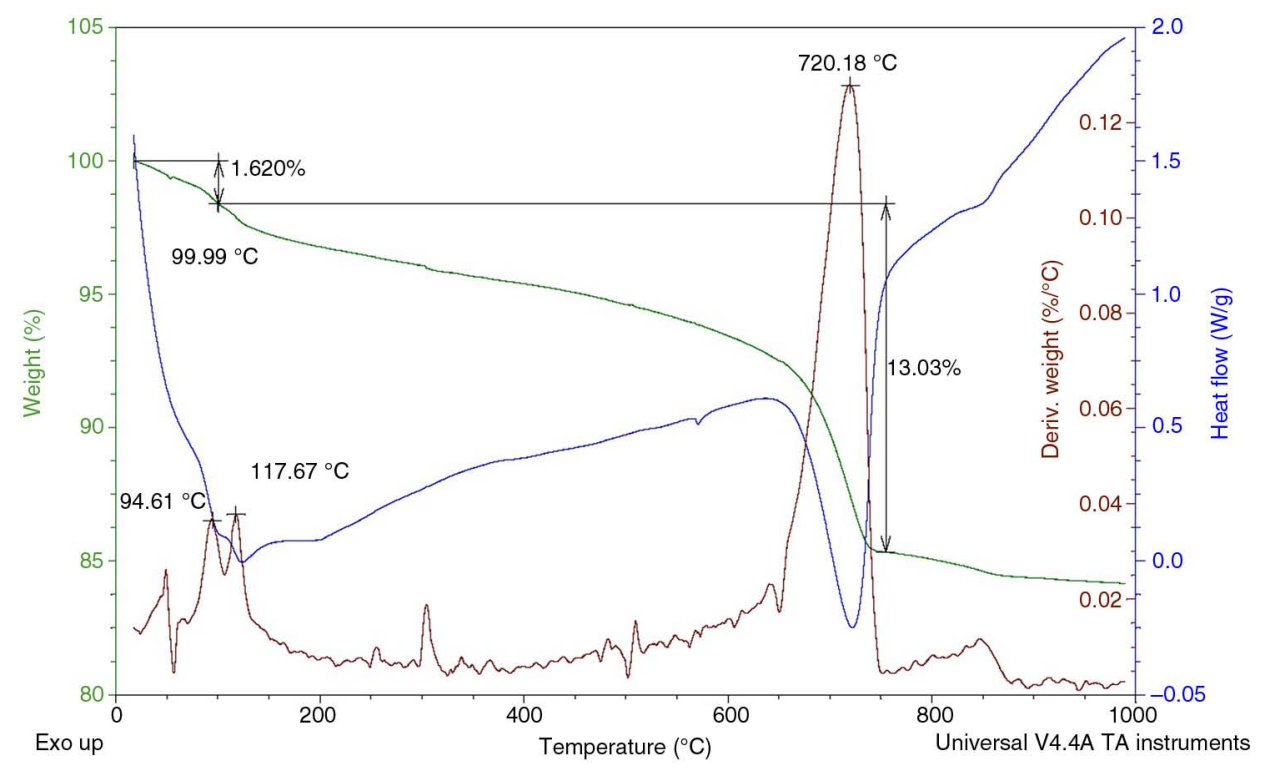

Figure 3. DSC-TGA test.

TABLE 5. Mortar mixtures proportions

\begin{tabular}{lcccccc}
\hline & M-Ref. & RA-10 $\%$ & RA-15 $\%$ & RA-25 $\%$ & RA-35\% & RA-45\% \\
\hline Standard Sand & 1350 & 1215 & 1147.5 & 1012.5 & 877.5 & 742.5 \\
RecycledAgg & - & 135 & 202.5 & 337.5 & 472.5 & 607.5 \\
Water & 225 & 225 & 225 & 225 & 225 & 225 \\
Cement & 450 & 450 & 450 & 450 & 450 & 450 \\
$\%$ Additive & - & - & $2 \%$ & $2 \%$ & $2 \%$ & $4 \%$ \\
\hline
\end{tabular}

water content of the mortar while maintaining workability and improving its strength, durability and shrinkage.

\subsection{Test Methodology}

The test program was organized in two phases: during the first phase, the fine recycled aggregate samples were characterized and the tests of consistency, flexural and compressive strength were carried out. During the second phase, and once all previously obtained results were analyzed, the batches that presented better results in the first phase were tested on bonding strength and shrinkage.

The following code was employed for the mixtures identification:

$$
\text { RA- }{ }^{\circ}-\mathrm{X} \%-\mathrm{Y} \%
$$

Where RA=Recycled aggregates,

$\mathrm{N}^{\circ}=$ Waste Treatment Plant. 1 and 2 for ceramic and concrete recycling line, the plant "Palentina" and 3 for concrete recycling line, the plant "Molar",
$\mathrm{X} \%=$ Recycled aggregates substitution percentage, $\mathrm{Y} \%=$ Additive use percentage over the weight of cement.

\section{EXPERIMENTAL RESULTS AND DISCUSSION}

\subsection{Physical properties of the fine aggregates}

According to the results shown in Table 2, obtained density values are lower than standardized sand, being similar to the values found in other researches $(7,8)$. Cement mortar attached to recycled aggregates causes poorer properties of RA, such as lower density and higher absorption. High absorption presented by fine recycled aggregates affects proportion of mortars, making the use of additives necessary in mortars manufactured with more than $10 \%$ substitution level. Fine recycled aggregate absorption is much higher compared to natural sand $(7,8,14)$. This characteristic may have a negative influence on mechanical performance of recycled mortars, because of the holes that may 
have been produced inside the material after the water has evaporated. The smallest fractions present the highest absorption level, when obtained from the same original concrete (15). Among the samples of recycled aggregates tested in accordance with the UNE-EN 1097-6 standard, the one which presented the highest water absorption coefficient was ceramic recycled aggregate with the value of 7.48. This value is lower in comparison to the values obtained by other authors in their research works $(8,10)$. The water absorption coefficient for concrete recycled aggregates RA 2 and RA3 were 6.35 and 6.12 respectively.

\subsection{Consistency}

One of the main inconveniences of such type of material is its workability. The consistency test determines the amount of water needed to manufacture mortar with an adequate workability. As it is shown in Figure 4, incorporation of recycled aggregates produces mortar consistency to decrease, being the use of additives necessary for easier mixing of diverse compounds. With increasing percentages of incorporated recycled aggregate, the addition of the additive proportions was needed to obtain consistency values between $165 \mathrm{~mm}$ and $185 \mathrm{~mm}$ according to the UNE-EN 1015-3 standard. The quantity of incorporated additives varied between $2 \%$ and $4 \%$ in cement weight; in no case the limit values established by the manufacturer were exceeded.Another possibility to improve the workability is to adjust the amount of water, reducing the additive incorporation rate. Consistency loss obtained incorporating $45 \%$ of recycled aggregate with respect to the reference batches are: $11 \%, 11.5 \%$ and $7 \%$ for aggregates RA-1, RA-2 and RA-3 respectively. However other studies showed better consistency incorporating up to $15 \%$ of fine concrete and $10 \%$ of fine ceramic aggregate $(16,17)$.

\subsection{Compression and flexural strength}

Prismatic specimens $(40 \times 40 \times 160 \mathrm{~mm})$ were manufactured, cast and wet cured at $20^{\circ} \mathrm{C}$ up to 28 days. The compression and flexural strength were evaluated according to the UNE-EN 1015-11, and were tested after the curing period.

In relation to mechanical strengths, the compression strength results (see Figure 5) of three types of recycled mortars are lower compared to the reference samples. Decrease in strength for batches containing $45 \%$ of recycled aggregates are: $23.8 \%$, $32.9 \%$ and $23.8 \%$ for aggregates RA-1, RA-2 and RA-3, respectively. These results comply with those obtained in another research (9), which proved that mortars containing recycled aggregates developed lower mechanical strength with respect to the reference mortars. However, the results obtained in recycled mortars containing RA-1 do not comply with those obtained in another studies $(9,16)$, which showed that replacement ratios of sand by brick waste of up to $40 \%$ increased the compressive strength of masonry mortars. Nevertheless, in

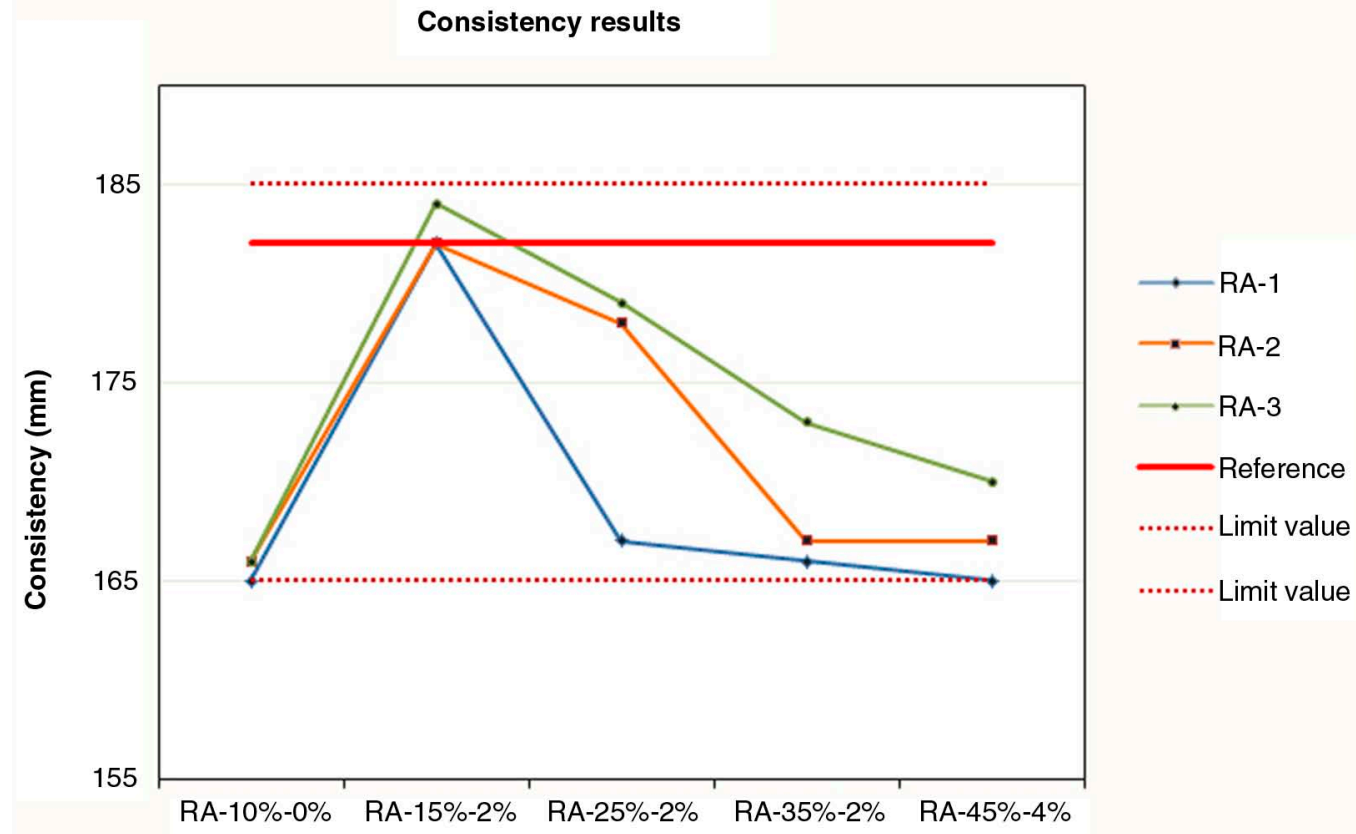

Figure 4. Consistency test results. 


\section{Compression strength (MPa)}

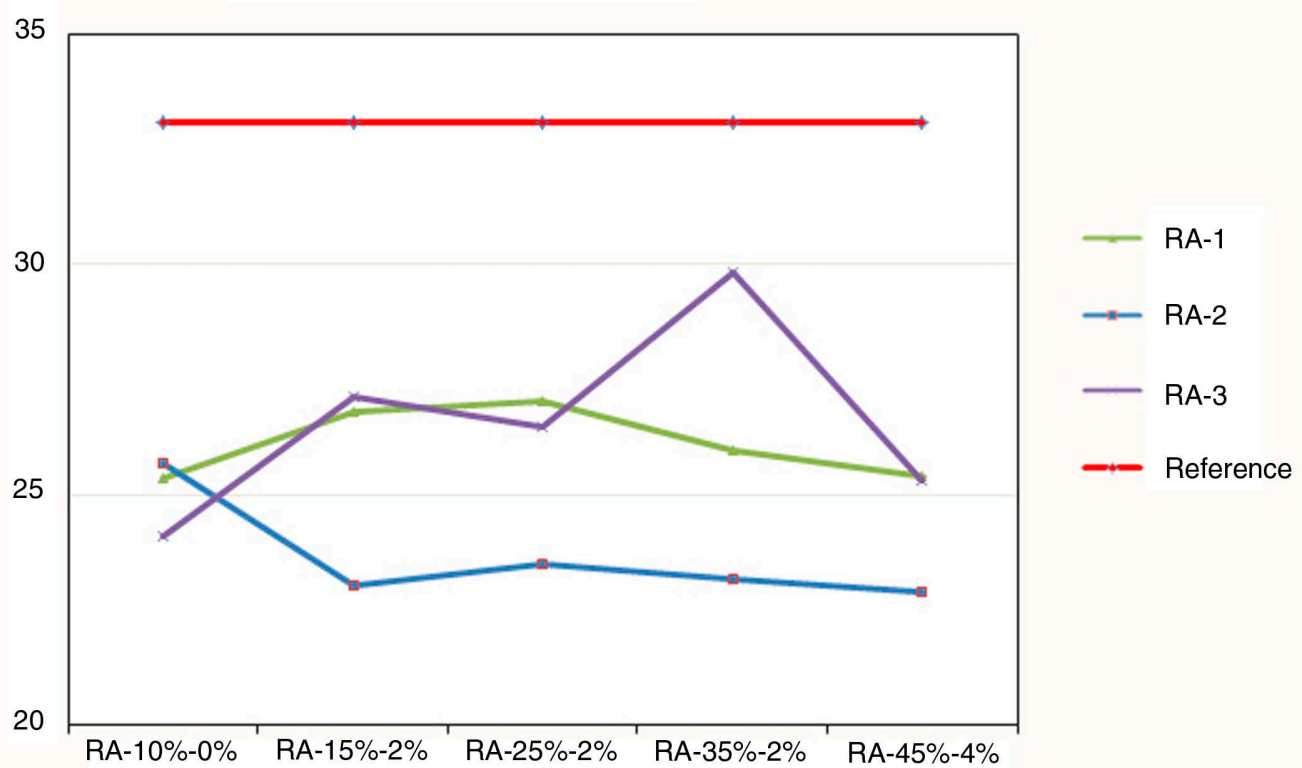

Figure 5. Compression strength test results.

Flexural strength (MPa)

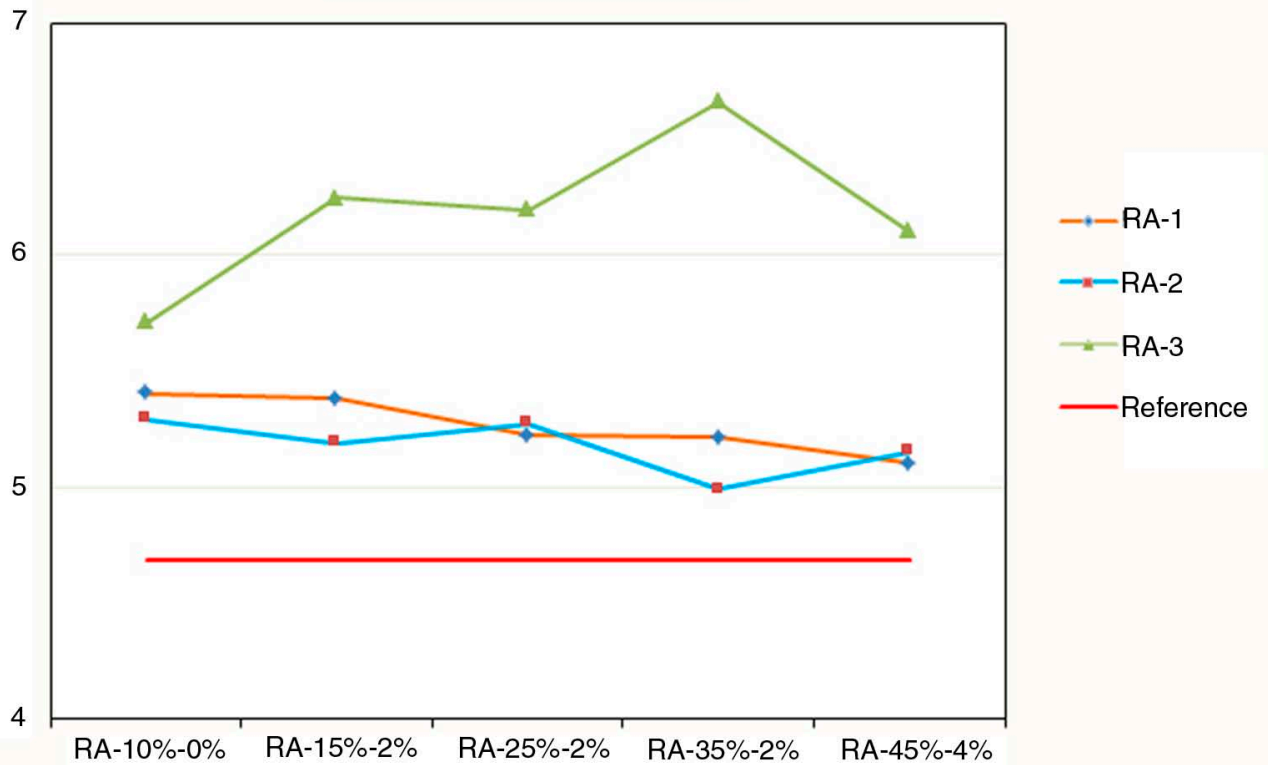

FIgURE 6. Flexural strength test results.

accordance with existing standards, the minimum acceptable value for compression strength is $7.5 \mathrm{MPa}$. Therefore it is not necessary to modify the mortar proportions.
On the other hand, the flexural strength results (see Figure 6) show higher values for three types of recycled mortars compared to the reference samples. The mixtures prepared using RA-3 from "Molar" 
treatment plant stand out, reaching an average value greater than $6 \mathrm{MPa}$. Improvements obtained with $45 \%$ of recycled aggregate substitution rate are $9.03 \%, 9.97 \%$ and $30.34 \%$ for the aggregates RA- 1 , RA-2 and RA-3 respectively. There are no standards that define the minimum acceptable value for the flexural strength of mortars.

\subsection{Bond strength}

In the second testing phase, bond strength and shrinkage tests were carried out. The bond strength test was carried out on a ceramic support of $400 \times 500 \times 50 \mathrm{~mm}$, with a specimen diameter of $50 \mathrm{~mm}$ and coating thicknesses of $10 \mathrm{~mm}$. The obtained results are shown in Table 6.

According to the results shown in Table 6, the three types of recycled mortars containing $45 \%$ of RA showed values exceeding the limit value of $0.30 \mathrm{~N} / \mathrm{mm}^{2}$ (established by the UNE-EN 998-1). Bond strength values obtained in recycled mortar produced using RA-3 gave the best results $\left(0.56 \mathrm{~N} / \mathrm{mm}^{2}\right)$ that is, higher than reference values. The mixtures elaborated with $45 \%$ of recycled ceramic aggregate presented the poorest values. This was probably because of the worse grading size distribution of this type of aggregate. Another research studies obtained values close to that of the reference using ceramic waste containing $40 \%$ of RA (9) and higher values containing 50\% of RA (16).

\subsection{Shrinkage}

Shrinkage tests show higher values for the three types of recycled aggregates studied. This test measures the changes in length of the mortar during

TABLE 6. Bond strength and shrinkage results

\begin{tabular}{lccc}
\hline & Bond Strength & & Max. Shrinkage \\
\cline { 2 - 2 } Mix & Average Value $\left(\mathbf{N} / \mathbf{m m}^{2}\right)$ & & $(\mathbf{m m} / \mathbf{m})$ \\
\hline Reference & $0.55 / \mathrm{A}(100)^{1}$ & 0.013 \\
RA-1-15\%-2\% & $0.49 / \mathrm{A}(100)^{1}$ & 0.013 \\
RA-1-25\%-2\% & $0.51 / \mathrm{A}(100)^{1}$ & 0.017 \\
RA-1-45\%-4\% & $0.43 / \mathrm{A}(100)^{1}$ & 0.021 \\
RA-2-10\%-0 $\%$ & $0.45 / \mathrm{A}(100)^{1}$ & 0.014 \\
RA-2-25\%-2\% & $0.54 / \mathrm{A}(100)^{1}$ & 0.018 \\
RA-2-45\%-4\% & $0.55 / \mathrm{A}(100)^{1}$ & 0.025 \\
RA-3-10\%-0 $\%$ & $0.47 / \mathrm{A}(100)^{1}$ & 0.016 \\
RA-3-25\%-2\% & $0.56 / \mathrm{A}(100)^{1}$ & 0.020 \\
RA-3-45\%-4\% & $0.56 / \mathrm{A}(100)^{1}$ & 0.021 \\
\hline
\end{tabular}

Note 1: Type of crack and affected surface $\%$. the first 24 hours, taking readings every 30 minutes. Table 6 shows the obtained results:

As observed in Table 6, increase in percentage of recycled aggregates incorporated in mortars produces higher shrinkage values due to the greater porosity and water absorption presented by RA. These characteristics significantly affect water migration mechanisms. These conclusions are similar to the findings of other researches (18). The mix that presents the most unfavourable value is the RA- $2-45 \%-4 \%$, being this value practically double than that of the reference mortars, however, complying with the limits established by Spanish standards.

\section{CONCLUSIONS}

The main conclusions that arise from this study are given below:

- Characteristics of three types of fine recycled aggregates are high content of $4 \mathrm{~mm}$ particles retained in sieve, as well as high water absorption and lower density values. Obtained water absorption values are between $5 \%$ and $10 \%$ that is an acceptable percentage for recycled aggregates.

- Recycled aggregate size distribution curves of three types of recycled aggregates are continuous and within the limits established by the standards.

- Due to the high water absorption of recycled aggregates, additives were incorporated to obtain workable mortars with flowing consistencies, without modifying the proportions. The additive was incorporated for substituting more than $10 \%$ in the three types of recycled aggregates.

- Mechanical performance of recycled aggregates is poorer than that of the reference in terms of compression, and higher in terms of flexural strength for the three types of recycled aggregates. In case of compression strength, the results obtained comply with the EN standards allowing its use in construction as masonry mortars, as well as rendering and plastering mortars.

- Results of the bond strength tests are similar to the reference in case of concrete RA and poorer in case of ceramic RA. Nevertheless, obtained values are adequate for any of the intended uses of this type of material.

- Recycled mortars shrinkage values are superior to those of the reference mortars. However, these values are within the limits established by the standards.

- In view of the above, it can be concluded that masonry mortars with 1:3:0.5 proportion, incorporating additive, may contain up to $45 \%$ of recycled aggregates from ceramic and concrete recycling processes, presenting characteristics that comply with the limits established by Spanish Standards. 


\section{ACKNOWLEDGEMENTS}

The authors gratefully acknowledge the support of the Architectural Construction and Control Department's laboratory of the Technical University School of Architecture (Madrid Polytechnic University) and the Chemistry and Polymers Department' laboratory of the University School of Technical Industrial Engineering (Madrid Polytechnic University).

The authors are also grateful to the BASF Construction Chemicals España S.L. for their technical support.

\section{REFERENCES}

1. Villoria, P.; del Río, M.; Porras, C.; de San Antonio, A. (2011) European Legislation and Implementation Measures in the Management of Construction and Demolition Waste. The Open Constr. Build. Technol. J. 5 [Suppl 2-M6], 156-161. http://dx.doi.org/10.2174/187483 6801105010156.

2. Etxeberria, M.; Vázquez, E.; Marí, A.; Barra, M. (2007) Influence of Amount of Recycled Coarse Aggregates and Production Process on Properties of Recycled Aggregate Concrete. Cem. Concr. Res. 37, 735-742. http://dx.doi. org/10.1016/j.cemconres.2007.02.002.

3. Tam, V.W.Y.; Wang, K.; Tam, C.M. (2008) Assessing Relationship among Properties of Demolished Concrete, Recycled Aggregate and Recycled Aggregate Concrete using Regression Analysis. J. Hazard. Mater. 152, 703-714. http://dx.doi.org/10.1016/j.jhazmat.2007.07.061.

4. Debieb, F.; Courard, L.; Kenai, S.; Degeimbre, R. (2009) Roller Compacted Concrete with Contaminated Recycled Aggregates. Constr. Build. Mater. 23, 3382-3387. http:// dx.doi.org/10.1016/j.conbuildmat.2009.06.031.

5. Yagishita, F.; Sano, M.; Yamada, M. (1994) Behaviour of Reinforced Concrete Beams Containing Recycled Coarse Aggregate. In: Lauritzen Erik, K., editor. Demolition and reuse of concrete. RILEM, 331-342.

6. Nishbayashi, S.; Yamura, K. (1998) Mechanical Properties and Durability of Concrete from Recycled Coarse Aggregate prepared by crushing Concrete. In: Proceedings of the second international RILEM, Symposium on Demolition and Reuse of Concrete and Masonry, 652-659.

7. Vegas, I.; Azkarate, I.; Juarrero, A.; Frias, M. (2009) Design and Performance of Masonry Mortars Made with
Recycled Concrete Aggregates. Mater. Construcc. 95 [295], 5-18. http://dx.doi.org/10.3989/mc.2009.44207.

8. Corinaldesi, V.; Moriconi, G. (2009) Behaviour of Cementitious Mortars containing Different kinds of Recycled Aggregate. Constr. Build. Mater. 23, 289-294. http://dx.doi. org/10.1016/j.conbuildmat.2007.12.006.

9. Jiménez, J.R.; Ayuso, J.; López, M.; Fernández, J.M.; De Brito, J. (2013) Use of Fine Recycled Aggregates from a Ceramic Waste in Masonry Mortar manufacturing. Constr. Build. Mater. 40, 679-690. http://dx.doi.org/10.1016/j. conbuildmat.2012.11.036.

10. Miranda, L.F.R.; Selmo, S.M.S. (2006) CDW recycled aggregate renderings: Part I - Analysis of the effect of materials finer than $75 \mu \mathrm{m}$ on mortar properties. Constr. Build. Mater. 20, 615-633. http://dx.doi.org/10.1016/j.conbuildmat. 2005.02 .025 .

11. Limbachiya, M.C.; Marrocchino, E.; Kouloris, A. (2007) Chemical-Mineralogical Characterisation of Coarse Recycled Concrete Aggregate. Waste Manage. 27, 201-208. http:// dx.doi.org/10.1016/j.wasman.2006.01.005.

12. Angulo, S.C.; Ulsen, C.; John, V.M.; Kahn, H.; Cincotto, M.A. (2009) Chemical-Mineralogical Characterization of C\&D Waste Recycled Aggregates from São Paulo, Brazil. Waste Manage. 29, 721-730. http://dx.doi.org/10.1016/j. wasman.2008.07.009.

13. Bianchini, G.; Marrocchino, E.; Tassinari, R.; Vaccaro, C. (2005) Recycling of Construction and Demolition Waste Materials: a Chemical and Mineralogical Appraisal. Waste Manage. 25, 149-159. http://dx.doi.org/10.1016/j. wasman.2004.09.005.

14. Rolón, J. C.; Nieves, D.; Huete, R.; Blandón, B.; Terán, A. (2007) Caracterización del Hormigón elaborado con Áridos Reciclados producto de la Demolición de Estructuras de Hormigón. Mater. Construcc. 57 [288], 5-15. http://dx.doi. org/10.3989/mc.2007.v57.i288.61.

15. Martín, M.; Zamorano, M.; Ruiz, A.; Valverde, I. (2011) Characterization of Recycled Aggregates Construction and Demolition Waste for Concrete production following the Spanish Structural Code EHE-08. Constr. Build. Mater. 25, 742-748. http://dx.doi.org/10.1016/j. conbuildmat.2010.07.012.

16. Silva, J.; de Brito, J.; Veiga, R. (2009) Incorporation of Fine Ceramics in Mortars. Constr. Build. Mater. 23, 556-564. http://dx.doi.org/10.1016/j.conbuildmat.2007.10.014.

17. Braga, M.; de Brito, J.; Veiga, R. (2012) Incorporation of Fine Concrete Aggregates in Mortars. Constr. Build. Mater. 36, 960-968. http://dx.doi.org/10.1016/j.conbuildmat.2012.06.031.

18. Martínez, I.; Etxeberria, M.; Pavón, E.; Díaz, N. (2013) A Comparative Analysis of the Properties of Recycled and Natural Aggregate in Masonry Mortars. Constr. Build. Mater. 49, 384-392. http://dx.doi.org/10.1016/j.conbuildmat. 2013.08.049. 